\title{
PENGARUH PEMAKAIAN EKSTRAK DAUN KEDONDONG (Spondias dulcis) SEBAGAI DESINFEKTAN ALAMI DALAM MENURUNKAN ANGKA KUMAN PADA PIRING MAKAN
}

\author{
Silmi Kaffah $^{1)}$, Zaeni Budiono ${ }^{2)}$, Tri Marthy Mulyasari ${ }^{3)}$ \\ DKK Cilacap, Poltekkes Kemenkes Semarang, Poltekkes Kemenkes Semarang
}

\begin{abstract}
Abstrak
Sumber kontaminasi dalam pengolahan pangan dapat berasal dari penggunaan wadah dan peralatan pengolahan yang kotor. Peralatan makan agar tidak menimbulkan gangguan kesehatan pada manusia serta memenuhi persyaratan kesehatan harus dicuci dengan benar yaitu meliputi pembuangan sisa makanan, pembilasan awal, pencucian, pembilasan akhir, sanitasi dan desinfeksi. Daun kedondong memiliki potensi antimikroba yang dapat digunakan sebagai desinfektan. Penelitian ini bertujuan untuk menganalisis pengaruh pemakaian ekstrak daun kedondong (Spondias dulcis) sebagai desinfektan alami dalam menurukan angka kuman pada piring makan. Jenis penelitian ini adalah Pre-experiment dengan pendekatan pre and post design. Hasil penelitian menunjukkan prosentase penurunan angka kuman sesudah diberi perlakuan adalah konsentrasi $4 \%$ sebesar $86,25 \%$, konsentrasi $8 \%$ sebesar $66,04 \%$, dan konsentrasi $12 \%$ sebesar $63,24 \%$. Hasil uji statistik Paired $T$ Test menunjukkan pada konsentrasi $4 \%$ nilai sig $0,174>0,05$, konsentrasi $8 \%$ nilai sig $0,126>0,05$, konsentrasi $12 \%$ nilai sig 0,194 >0,05, dari ketiga konsentrasi nilai sig lebih besar dari 0,05 berarti tidak ada perbedaan angka kuman sebelum dan sesudah diberi perlakuan. Hasil uji ANOVA nilai sig $0,356>$ dari 0,05 berarti tidak ada perbedaan penurunan angka kuman yang signifikan pada piring makan antara penggunaan konsentrasi $4 \%, 8 \%$ maupun $12 \%$. Kesimpulan penelitian ini bahwa tidak ada pengaruh pemakaian ekstrak daun kedondong (Spondias Dulcis) sebagai desinfektan alami dalam menurunkan angka kuman pada piring. Disarankan piring yang telah dicuci bersih sebaiknya didesinfeksi agar angka kuman pada piring sesuai persyaratan.
\end{abstract}

Kata kunci: Ekstrak daun kedondong; Angka kuman

\begin{abstract}
Sources of contamination in the processing of food can comes from the use of containers and processing equipment are dirty. In order for the tableware does not cause health problems in humans as well as to meet the health requirements should be washed properly includes the disposal of leftovers, the initial flushing, the flushing end, laundering, sanitation and disinfection. Leaf kedondong have a potential antimicrobial who can be used as a disinfectant. This research aims to analyze influence of consumption leaf kedondong extract (spondias dulcis) as a natural disinfectant in lowering the number of germs on a plate. The type of research is Pre-experiment with the approach pre and post design. The results of the research show that decrease in the number of germs after being given the treatment, concentration of $4 \%$ is $86.25 \%$, concentration of $8 \%$ is $66.04 \%$, and concentration of $12 \%$ is $63.24 \%$. The test of statistical Paired T-test results showed concentrations of $4 \%$ has a value of sig $0.174>$ 0.05 , the concentration of $8 \%$ has a value of sig $0.126>0.05$, concentration of $12 \%$ has a value of sig $0.194>0.05$. The third concentration value sig is higher than 0.05 means there is no difference in the number of germs before and after being given the treatment. ANOVA test results has a value of sig $0.356>$ of 0.05 means there is no difference significant decrease in the number of germs on a dinner plate between the concentrations of $4 \%, 8 \%$ or $12 \%$. The conclusion of this research that there is no influence of consumption leaf kedondong extract (spondias dulcis) as a natural disinfectant in lowering the number of germs on a plate. It is recommended, the plate that has been washed clean, should disinfected so the number of germs on the plate fits the requirements.
\end{abstract}

Keywords: Leaf kedondong extract; number of germs

\footnotetext{
1) E-mail: silmikaff25@gmail.com

2) E-mail: pakzaeni@gmail.com

3) E-mail: trimarthymulyasari@gmail.com
} 


\section{Pendahuluan}

Undang-undang Nomor 18 Tahun 2012 pasal 1 ayat 30 Tentang Pangan menyebutkan, sanitasi pangan adalah upaya untuk menciptakan dan mempertahankan kondisi pangan yang sehat, dan higienis yang bebas dari bahaya cemaran biologis, kimia dan benda lain. Peraturan Pemerintah RI Nomor 28 Tahun 2004 pasal 1 ayat 7 Tentang Keamanan Mutu Dan Gizi Pangan menyebutkan, keamanan pangan adalah kondisi dan upaya yang diperlukan untuk mencegah pangan dari kemungkinan cemaran biologis, dan benda lain yang dapat mengganggu, merugikan, dan membahayakan kesehatan manusia. Keputusan Menteri Kesehatan RI Nomor 1098 Tahun 2003 pasal 1 ayat 4 Tentang Persyaratan Higiene Sanitasi Rumah Makan dan Restoran menyebutkan, higiene sanitasi makanan adalah upaya untuk mengendalikan faktor makanan, orang, tempat dan perlengkapannya yang dapat atau mungkin dapat menimbulkan penyakit atau gangguan kesehatan.

Higiene dan sanitasi makanan sangat penting terutama di tempat-tempat umum yang erat kaitannya dengan pelayanan untuk orang banyak (Rara Marisdayana dkk, 2017, h.377). Kemajuan zaman membuat semakin banyak orang yang tidak sempat menyiapkan sendiri makanan yang akan dikonsumsi, dengan demikian mereka tergantung pada pelayanan jasa boga seperti warung makan, restoran, katering, kafe bahkan warung tenda dan lesehan, untuk memenuhi kebutuhan makanannya (Hiasinta A. Purnawijayanti, 2001, h.1). Penelitian di Amerika Serikat melaporkan, orang yang gemar makan di restoran dua kali lebih besar menghadapi resiko keracunan makanan dibandingkan dengan orang yang memakan makanan di rumah. Studi baru asal Center for Science in the Public Interest (CSPI) menyebutkan, para peneliti menganalisa kasus 10.408 keracunan makanan dari data Pusat Pengawasan dan Pencegahan Penyakit AS (CDC), data tersebut meliputi kasus dari 2002 hingga 2011, selama periode sembilan tahun para peneliti menemukan lebih dari 1.610 keracunan terjadi pada lebih dari 28.000 orang terjadi di restoran, sementara itu hanya 893 keracunan yang terjadi pada sekitar 13.000 orang terjadi di rumah(Unoviana Kartika, 2014).Badan Pengawas Obat dan Makanan (BPOM) Republik Indonesia menyebutkan bahwa kontaminasi mikroba lebih sering menyebabkan keracunan pangan dibandingkan bahan kimia (BPOM, 2006).

Sumber kontaminasi dalam pengolahan pangan dapat berasal dari penggunaan wadah dan peralatan pengolahan yang kotor (Srikandi Fardiaz, 1989, h.7 dalam Apriyati Ningsih, 2015). Sebuah kasus keracunan yang diakibatkan oleh peralatan makan terjadi di

Universitas Al-Azhar Kairo yang mengakibatkan 180 mahasiswa dirawat di rumah sakit, berdasarkan hasil uji laboratorium menunjukkan bahwa peralatan makan yang kotor di kantin asrama universitas menjadi penyebab terjadinya keracunan makanan tersebut (Ahram, 2013).

Peralatan makan agar tidak menimbulkan gangguan kesehatan pada manusia serta memenuhi persyaratan kesehatan harus dicuci dengan benar yaitu meliputi pembuangan sisa makanan, pembilasan awal, pencucian, pembilasan akhir, sanitasi dan desinfeksi (Hiasinta A Purnawijayanti, 2001, h.35). Teknik pencucian yang benar dan sesuai standar diharapkan dapat menurunkan angka kuman pada peralatan makan agar jumlah angka kuman total yang terdapat pada peralatan makan dapat memenuhi syarat Kepmenkes Nomor 1096 Tahun 2011 Tentang Higiene Sanitasi Jasa Boga yaitu angka kuman 
total pada peralatan makan 0 (nol) dan E-coli 0 (nol).

Menurut hasil survey pendahuluan yang dilakukan oleh penelitipada 20 Oktober 2018 terhadap kualitas mikrobiologi pada piring makan, jumlah angka kuman pada piring di Kantin Kampus 7 Poltekkes Kemenkes Semarang yang telah dicuci dengan sabun cuci dan air mengalir sebanyak 3.566koloni $/ \mathrm{cm}^{2}$. Hasil angka kuman tersebut menunjukkan bahwa piring yang telah dicuci bersih dengan menggunakan sabun cuci dan air mengalir, secara fisik terlihat bersih namun setelah diperiksa di laboratorium menunjukkan bahwa masih terdapat angka kuman yang tinggi dan tidak memenuhi syarat Kepmenkes Nomor 1096 Tahun 2011. Berdasarkan pernyataan tersebut maka hal yang perlu dilakukan setelah proses pencucian adalah dengan melakukan desinfeksi pada peralatan makan guna menurunkan cemaran mikroba yang masih menempel pada peralatan makan.

Secara garis besar desinfeksi dibedakan menjadi desinfeksi non kimiawi dan kimiawi, desinfeksi non kimiawi adalah mematikan mikroorganisme melalui aktivitas fisik dari energi yang dimilikinya yaitu dengan cara merendam dengan air panas bersuhu $80^{\circ}$ atau lebih, penggunaan uap air panas dan radiasi sinar, sedangkan desinfeksi kimiawi adalah membunuh mikroorganisme menggunakan senyawa kimia atau dapat disebut juga sebagai desinfektan (Hiasinta A. Purnawijayanti, 2001, h.26).

Daun kedondong memiliki potensi antimikroba yang dapat digunakan sebagai desinfektan. Menurut Hurri Inayati (2007) daun kedondong yang diekstraksi dengan menggunakan tiga pelarut yaitu metanol, aseton, dan heksana, ekstrak metanol menunjukan hasil positif untuk senyawa saponin, alkaloid, dan tanin berdasarkan uji fitokimia semakin tinggi konsentrasi ekstrak daun kedondong maka semakin besar zona hambat yang dihasilkan. Silvia Fitriani, dkk (2013) menunjukan bahwa adanya pengaruh pemberian ekstrak daun kedondong terhadap pertumbuhan misselia jamur A. Flavus dengan berbagai konsentrasi, yaitu dengan konstentrasi $8 \%$ memiliki daya hambat pertumbuhan sebesar $77,82 \%$, dan pada konstentrasi $10 \%$ memiliki daya hambat pertumbuhan sebesar $80,37 \%$.

Tujuan penelitian ini untuk mengetahui pengaruh pemakaian ekstrak daun kedondong (Spondias dulcis) sebagai desinfektan alami dalam menurunkan angka kuman pada piring makan di kantin kampus 7 Poltekkes Kemenkes Semarang.

\section{Bahan dan Metode}

Alat yang digunakan dalam penelitian ini antara lain timbangan, gelas ukur, erlenmetyer, beaker glass, kertas saring, corong plastik/ kaca, evaporator, gunting, bunsen, termos, karet, plastik mika, label, kertas payung, cawan petri steril, pipet ukur steril, autoklaf, korek api.

Bahan yang digunakan dalam penelitian ini antara lain daun kedondong segar (Spondias dulcis), etanol 96\%, aquades, media transport $(\mathrm{NaCl})$, swab, alkohol $70 \%$, sampel alat makan.

Pembuatan ekstrak daun kedondong

Pembuatan ekstrak daun kedondong menggunakan metode maserasi. Kurang lebih sebanyak $1 \mathrm{~kg}$ daun kedondong segar dikeringkan dibawah sinar matahari selama 4 hari, hingga daun kering patah berwarna coklat. Daun yang telah dikeringkan kemudian dihaluskan hingga menjadi serbuk, serbuk yang dihasilkan kurang lebih 250 gr. Masukkan sebanyak 300-500 ml larutan etanol $96 \%$ kedalam beaker glass yang telah berisi serbuk, yang bertujuan untuk membasahi serbuk. Kemudian tambahkan lagi etanol 96\% kedalam beaker berisi serbuk dengan perbandingan 1:3 (serbuk:etanol 96\%). Kemudian daun direndam atau dimaserasi selama 24 jam. Setelah 24 jam kemudian saring ekstrak dengan ampas menggunakan kertas saring. Filtrat yang telah terpisah dari ampas kemudian di evaporasi menggunakan evaporator selama 24 jam dengan suhu $50^{\circ} \mathrm{C}$. Setelah ekstrak siap digunakan kemudian campurkan ekstrak dengan pelarut aquades sesuai dengan konsentrasi yang telah ditentukan $(4 \%, 8 \%, 12 \%)$.

\section{Pengambilan sampel angka kuman pada piring makan}

Sterilkan alat dan bahan yang akan digunakan menggunakan autoklaf. Aseptiskan meja kerja dan tangan menggunakan alkohol $70 \%$. Ambil swab dan masukkan ke dalam tabung yang berisi media transpor, kemudian swab ditekan ke dinding tabung untuk meniriskan airnya. Usapkan swab yang telah ditiriskan pada piring makan yang akan diperiksa jumlah angka kumannya, dengan cara membagi piring menjadi 4 juring, kemudian ambil usapan pada dua juring yang berlawanan. Setiap bidang permukaan yang diusap dilakukan pengulangan 3 kali. Setelah diusapkan, segera masukkan swab ke dalam tabung yang berisi media transpor, patahkan tangkai swab, aseptiskan mulut tabung, kemudian tutup kembali. Beri label pada setiap sampel yang diperiksa. 


\section{Pemeriksaan angka kuman}

Ambil suspensi (hasil usapan) sebanyak 1 ml masukkan ke dalam cawan petri steril. Tuangkan media PCA sampai 1/3 tinggi cawan ( $\pm 5 \mathrm{ml}$ ). Homogenkan dengan membentuk angka 8 sebanyak 8 kali. Inkubasikan pada suhu $\pm 35^{\circ} \mathrm{C}$, selama $2 \times 24$ jam dalam inkubator. Lakukan pengamatan (hitung koloni dalam cawan). Hitung koloni pada alat makan tersebut menggunakan rumus: $\sum$ koloni $1 \mathrm{ml}$ x V x $\frac{\mathrm{P}}{\mathrm{Q}}$

\section{Hasil dan Pembahasan}

a. Hasil Perhitungan Angka Kuman Pada Piring Sebelum Didesinfeksi Menggunakan Ekstrak Daun Kedondong (Spondias dulcis)

Perhitungan angka kuman sebelum diberi perlakuan menggunakan ekstrak daun kedondong dengan konsentrasi 4\%, $8 \%$, $12 \%$ bertujuan untuk mengetahui angka kuman total pada 9 piring sampel yang diperiksa yaitu piring yang diambil dari kantin X. Angka kuman sebelum diberi perlakuan digunakan sebagai pembanding dengan angka kuman sesudah diberi perlakuan, agar diketahui terjadi kenaikan atau penurunan. Hasil perhitungan angka kuman pada piring sebelum didesinfeksi menggunakan ekstrak daun kedondong (Spondias dulcis) seperti pada tabel 1.

Tabel 1: Hasil Perhitungan Angka Kuman Pada Piring Sebelum Didesinfeksi Menggunakan Ekstrak Daun Kedondong (Spondias dulcis) Dengan Konsentrasi 4\%, $8 \%, 12 \%$

\begin{tabular}{cccc}
\hline Replikasi & Pre 4\% & Pre 8\% & Pre 12\% \\
\hline 1 & 430 & 130 & 180 \\
2 & 70 & 395 & 90 \\
3 & 220 & 120 & 80 \\
\hline Min & $\mathbf{7 0}$ & $\mathbf{1 2 0}$ & $\mathbf{8 0}$ \\
\hline Max & $\mathbf{4 3 0}$ & $\mathbf{3 9 5}$ & $\mathbf{1 8 0}$ \\
\hline Rerata & $\mathbf{2 4 0}$ & $\mathbf{2 1 5}$ & $\mathbf{1 1 7}$ \\
\hline
\end{tabular}

Berdasarkan hasil perhitungan angka kuman pada piring, rerata angka kuman pada piring sebelum diberi perlakuan dengan konsentrasi 4\% adalah 240 koloni $/ \mathrm{cm}^{2}$, konsentrasi $8 \%$ adalah 215 koloni $/ \mathrm{cm}^{2}$, dan konsentrasi $12 \%$ adalah

117 koloni $/ \mathrm{cm}^{2}$. Keputusan Menteri Kesehatan Republik Indonesia Nomor 1096 Tahun 2011 Tentang Higiene Sanitasi Jasaboga menyebutkan bahwa persyaratan angka kuman pada peralatan makan adalah 0 (nol).

Berdasarkan hasil perhitungan angka kuman pada piring sampel sebelum diberi perlakuan menggunakan ekstrak daun kedondong $(4 \%, 8 \%, 12 \%)$ dapat diketahui bahwa rerata angka kuman yang terdapat pada piring makan di Kantin $X$ tidak memenuhi syarat. Angka kuman pada piring di Kantin X yang masih melebihi nilai persyaratan dapat disebabkan oleh beberapa hal terkait dengan cara penanganan piring seperti teknik pencucian, sumber air yang digunakan untuk pencucian, dan cara penyimpanan piring.

Hiasinta A Purnawijayanti (2001, h. 35) menyebutkan teknik pencucian peralatan meliputi pembuangan sisa makanan, pembilasan awal pada sisa makanan, selanjutnya proses pencucian yang dilakukan dalam bak pertama yang berisi larutan detergen, berikutnya adalah pembilasan yang dilakukan pada bak kedua dengan menggunakan air hangat dan air

mengalir, kemudian sanitasi atau desinfeksi, dan tahapan terakhir adalah

pengeringan peralatan yang perlu diperhatikan pada pengeringan adalah pada peralatan saji tidak boleh dikeringkan menggunakan lap atau serbet, karena kemungkinan justru akan menyebabkan kontaminasi ulang. Peralatan yang sudah disanitasi juga tidak boleh dipegang sebelum siap digunakan.

Keputusan Menteri Kesehatan RI Nomor 1098 Tahun 2003 Tentang Persyaratan Higiene Sanitasi Rumah Makan Dan Restoran menyebutkan, Air yang digunakan untuk keperluan pencucian dilengkapi dengan air panas dengan suhu $40^{\circ} \mathrm{C}-80^{\circ} \mathrm{C}$ dan air dingin yang bertekanan $15 \mathrm{psi}\left(1,2 \mathrm{~kg} / \mathrm{cm}^{2}\right)$.

Keputusan Menteri Kesehatan RI Nomor 1098 Tahun 2003 Tentang Persyaratan Higiene Sanitasi Rumah Makan Dan Restoran menyebutkan, bahwa semua peralatan yang kontak dengan makanan harus disimpan dalam keadaan kering dan bersih. Cangkir, mangkok, gelas dan sejenisnya cara penyimpanannya harus dibalik. Rak-rak penyimpanan peralatan dibuat anti karat, rata dan tidak aus/rusak. Laci-laci penyimpanan peralatan terpelihara kebersihannya. Ruang penyimpanan peralatan tidak lembab, terlindung dari sumber pengotor atau kontaminasi dari binatang perusak.

Berdasarkan serangkaian dalam penanganan piring tersebut, penangan piring pada Kantin X tidak memenuhi 
syarat. Pada teknik pencucian, Kantin X tidak menyediakan air hangat untuk proses pencucian, tidak ada tahapan desinfeksi pada serangkaian proses pencucian, poses pengeringan menggunakan lap kanebo, dan kegiatan pencucian dilakukan di lantai yang diplester semen dengan hanya tersedia satu ember yang digunakan sebagai tempat rendaman piring kotor. Piring yang telah dicuci hanya diletakkan pada meja besar tanpa penutup yang berada di ruang tengah kantin. Beberapa uraian tersebut dapat menjadi penyebab banyaknya jumlah angka kuman yang terdapat pada piring makan di Kantin $\mathrm{X}$ meskipun piring telah dicuci menggunakan detergen.

Anwar dkk menyebutkan bahwa kontaminasi makanan dapat melalu 4 faktor antara lain penjamah makanan, cara pengolahan makanan, tempat pengolahan makanan, dan perlengkapan/ peralatan dalam pengolahan makanan. Sehubungan dengan hal tersebut, jumlah angka kuman pada piring di Kantin $X$ yang masih melebihi persyaratan dapat mengakibatkan kontaminasi pada makanan yang berasal dari piring tersebut. Beberapa cara dapat dilakukan untuk menurunkan angka kuman pada piring guna mencegah kontaminasi pada makanan, salah satunya dengan cara desinfeksi.

b. Hasil Perhitungan Angka Kuman Pada Piring Sesudah Didesinfeksi Menggunakan Ekstrak Daun Kedondong (Spondias dulcis)

Perhitungan angka kuman sesudah diberi perlakuan menggunakan ekstrak daun kedondong dengan konsentrasi 4\%, $8 \%$, $12 \%$ bertujuan untuk mengetahui angka kuman total pada 9 sampel piring yang diperiksa sesudah diberi perlakuan. Angka kuman sesudah diberi perlakuan digunakan sebagai pembanding dengan angka kuman sebelum diberi perlakuan, agar diketahui terjadinya perbedaan angka kuman. Hasil perhitungan angka kuman

pada piring sesudah didesinfeksi menggunakan ekstrak daun kedondong (Spondias dulcis) seperti pada tabel 2.

Berdasarkan hasil perhitungan angka kuman pada piring, rerata angka kuman pada piring sesudah diberi perlakuan ekstrak daun kedondong (Spondias dulcis) dengan konsentrasi $4 \%$ adalah 33 koloni $/ \mathrm{cm}^{2}$, konsentrasi $8 \%$ adalah 73 koloni $/ \mathrm{cm}^{2}$, konsentrasi $12 \%$ adalah 43 koloni $/ \mathrm{cm}^{2}$.
Tabel 2: Hasil Perhitungan Angka Kuman Pada Piring Sesudah Didesinfeksi Menggunakan Ekstrak Daun Kedondong (Spondias dulcis) Dengan Konsentrasi 4\%, $8 \%, 12 \%$

\begin{tabular}{cccc}
\hline Replikasi & Post 4\% & Post 8\% & $\begin{array}{c}\text { Post } \\
12 \%\end{array}$ \\
\hline 1 & 35 & 20 & 35 \\
2 & 15 & 145 & 30 \\
3 & 50 & 55 & 65 \\
\hline Min & $\mathbf{1 5}$ & $\mathbf{2 0}$ & $\mathbf{3 0}$ \\
\hline Max & $\mathbf{3 5}$ & $\mathbf{1 4 5}$ & $\mathbf{6 5}$ \\
\hline Rerata & $\mathbf{3 3}$ & $\mathbf{7 3}$ & $\mathbf{4 3}$ \\
\hline
\end{tabular}

Keputusan Menteri Kesehatan Republik Indonesia Nomor 1096 Tahun 2011 Tentang Higiene Sanitasi Jasaboga menyebutkan bahwa persyaratan angka kuman pada peralatan makan adalah 0 (nol). Berdasarkan persyaratan tersebut angka kuman pada piring sesudah diberi perlakuan ekstrak daun kedondong dengan konsentrasi $4 \%$, $8 \%$, dan $12 \%$, masih melebihi nilai persyaratan.

Pelczar dan Chan (2008) mengatakan adanya bahan organik lain dapat menurunkan dengan nyata keefektifan zat kimia antimikrobial dengan cara menginaktifkan bahan-bahan tersebut. Penelitian ini memanfaatkan senyawa desinfektan dalam daun kedondong tanpa proses pemurnian, sehingga kemungkinan banyak senyawa lain yang terbawa dalam ekstrak.

c. Perhitungan Prosentase Penurunan Angka Kuman Pada Piring Sesudah Didesinfeksi Menggunakan Ekstrak Daun Kedondong (Spondias dulcis)

Perhitungan prosentase penurunan angka kuman digunakan untuk mengetahui seberapa besar adanya penurunan angka kuman pada piring sesudah diberikan perlakuan. Terdapat 3 variasi dosis/ konsentrasi ekstrak daun kedondong (Spondias dulcis) yang diaplikasikan pada piring makan yaitu $4 \%, 8 \%$, dan $12 \%$, dengan replikasi atau pengulangan masingmasing konsentrasi sebanyak 3 kali. Angka kuman pada piring dihitung sebelum dan 
sesudah diberi perlakuan menggunakan ekstrak daun kedondong dengan konsentrasi $4 \%$, $8 \%$, dan $12 \%$, kemudian dihitung ratarata dan prosentasenya. Hasil perhitungan prosentase penurunan angka kuman pada piring sesudah didesinfeksi menggunakan ekstrak daun kedondong (Spondias dulcis)seperti pada tabel

Tabel 3: Hasil Perhitungan Prosentase Penurunan Angka Kuman Pada Piring

Sesudah Didesinfeksi Menggunakan Ekstrak Daun kedondong (Spondias dulcis)

\begin{tabular}{ccccccc}
\hline $\begin{array}{c}\text { Rep } \\
\text { lika } \\
\text { si }\end{array}$ & Pre & $\begin{array}{r}\text { Post } \\
4 \%\end{array}$ & Pre & $\begin{array}{r}\text { Post } \\
8 \%\end{array}$ & Pre & $\begin{array}{c}\text { Post } \\
12 \%\end{array}$ \\
\hline 1 & 430 & 35 & 130 & 20 & 180 & 35 \\
2 & 70 & 15 & 395 & 145 & 90 & 30 \\
3 & 220 & 50 & 120 & 55 & 80 & 65 \\
\hline $\begin{array}{c}\text { Rer } \\
\text { ata }\end{array}$ & $\mathbf{2 4 0}$ & $\mathbf{3 3}$ & $\mathbf{2 1 5}$ & $\mathbf{7 3}$ & $\mathbf{1 1 7}$ & $\mathbf{4 3}$ \\
\hline $\mathbf{\%})$ & $\mathbf{8 6 , 2 5 \%}$ & $\mathbf{6 6 , 0 4 \%}$ & $\mathbf{6 3 , 2 4 \%}$
\end{tabular}

Berdasarkan data perhitungan angka kuman sebelum dan sesudah diberi perlakuan dengan konsentrasi 4\%, $8 \%$, dan $12 \%$ dapat diketahui prosentase penurunan angka kuman. Prosentase penurunan angka kuman dari masing-masing konsentrasi adalah konsentrasi $4 \%$ sebesar 86,25\%, konsentrasi $8 \%$ sebesar $66,04 \%$, dan konsentrasi $12 \%$ sebesar $63,24 \%$.

Penurunan angka kuman sebelum dan sesudah diberi perlakuan disebabkan oleh kandungan antibakteri yang terdapat pada ekstrak daun kedondong (Spondias dulcis). Daun kedondong (Spondias dulcis) mengandung senyawa flavonoid, saponin, alkaloid, dan tanin. Berdasarkan uji aktivitas filtrat, daun kedondong bangkok tua yang segar secara umum memiliki aktivitas antibakteri yang lebih besar dibandingkan dengan daun yang muda (Hurri Inayati, 2007).

Dinafishy (2016) menyebutkan daun kedondong di dalamnya mengandung senyawa yang berfungsi sebagai antimikroba, senyawa tersebut antara lain Flavonoid, Saponin, Alkaloid dan Tanin. Flavonoid membentuk senyawa kompleks terhadap protein sel bakteri dan merusak membran sel tanpa dapat diperbaiki lagi. Alkaloid mengganggu komponen penyusun peptidoglikan pada sel bakteri, sehingga lapisan dinding sel tidak terbentuk secara utuh dan menyebabkan kematian sel. Tanin dapat menghambat metabolisme sel, menganggu sintesa dinding sel, dan protein dengan mengganggu aktivitas enzim. Saponin bereaksi dengan porin membentuk ikatan polimer yang kuat sehingga mengakibatkan rusaknya porin, akibatnya sel bakteri kekurangan nutrisi dan mati.

Berdasarkan penelitian yang dilakukan oleh I Wayan Sudira dkk (2011) daun

kedondong mampu menghambat pertumbuhan bakteri E Carotovora dengan konsentrasi $4 \%$ pada media PPGA dan lidah buaya. Silvia Fitriani, dkk (2013) menunjukan bahwa daun kedondong mampu menghambat pertumbuhan misselia jamur A. Flavus dengan berbagai konsentrasi, dan pada konsentrasi $10 \%$ mampu memberikan daya hambat sebesar 80,37\%. Jatmiko Susilo dkk menyebutkan, ekstrak etanol daun kedondong (Spondias dulcis) terbukti mempunyai aktivitas antibakteri terhadap bakteriS. aureus resisten dan $E$. coli resisten dengan berbagai konsentrasi $(2 \%, 4 \%, 8 \%)$.

d. Hasil Analisis Pengaruh Pemakaian Ekstrak Daun Kedondong (Spondias dulcis) Terhadap Angka Kuman Pada Piring

Analisis data bivariat menggunakan Uji statistik digunakan untuk mengetahui pengaruh pemakaian ekstrak daun kedondong (Spondias dulcis) dengan konsentrasi 4\%, 8\%, dan $12 \%$ terhadap angka kuman pada piring. Uji statistik yang digunakan untuk mengalisis data bivariat adalah uji Paired T Test. Variabel dikatakan berhubungan atau signifikan apabila nilai sig $<0,05$. Hasil perhitungan uji statistik Paired $T$ Test terhadap angka kuman sebelum dan sesudah diberi perlakuan menggunakan ekstrak daun kedondong dengan konsentrasi 4\%, 8\%, 12\% seperti pada tabel 4 .

Tabel 4: Hasil Uji Paired T Test Angka Kuman Pada Piring Sebelum dan Sesudah Diberi Perlakuan Ekstrak Daun Kedondong (Spondias dulcis) Dengan Konsentrasi 4\%, $8 \%$, dan $12 \%$

\begin{tabular}{|c|c|c|c|c|}
\hline \multicolumn{2}{|c|}{ Perlakuan } & \multirow{2}{*}{$\frac{\mathrm{T}}{-2,070}$} & \multirow{2}{*}{$\frac{\mathrm{df}}{2}$} & \multirow{2}{*}{$\begin{array}{l}\begin{array}{c}\text { Sig. (2- } \\
\text { tailed) }\end{array} \\
, 174\end{array}$} \\
\hline $\begin{array}{l}\text { Pair } \\
1\end{array}$ & $\begin{array}{l}4 \%- \\
\text { Pre } 4 \%\end{array}$ & & & \\
\hline $\begin{array}{l}\text { Pair } \\
2\end{array}$ & $\begin{array}{l}8 \%- \\
\text { Pre } 8 \%\end{array}$ & $-2,543$ & 2 & ,126 \\
\hline $\begin{array}{l}\text { Pair } \\
3\end{array}$ & $\begin{array}{l}12 \%- \\
\text { Pre } 12 \%\end{array}$ & $-1,924$ & 2 & ,194 \\
\hline
\end{tabular}
ekstrak daun kedondong (Spondias dulcis) menggunakan uji statistik Paired T Test menunjukkan bahwa pada perlakuan

ekstrak daun kedondong dengan konsentrasi $4 \%$ diperoleh nilai sig $0,174>$ 
0,05 konsentrasi $8 \%$ diperoleh nilai sig $0,126>0,05$ konsentrasi $12 \%$ diperoleh nilai sig $0,194>0,05$, berarti tidak ada perbedaan angka kuman pada piring

sebelum dan sesudah didesinfeksi menggunakan ekstrak daun dedondong (Spondias dulcis) dari ketiga konsentrasi tersebut.

Berdasarkan hasil uji statistik Paired $T$ Test tersebut, diketahui bahwa tidak ada perbedaan yang signifikan pada angka kuman piring sesudah diberi perlakuan ekstrak daun kedondong (Spondias dulcis) dengan konsentrasi 4\%, 8\%, 12\%. Hal tersebut dikarenakan jumlah angka kuman dari sebelum didesinfeksi dengan sesudah didesinfeksi penurunannya tidak signifikan, sehingga hal tersebut menyebabkan hasil uji pada Paired $T$ Test terjadi penurunan dengan ditandai nilai negatif (-) namun tidak berarti.Penurunan angka kuman yang tidak berarti, dapat disebabkan karena kandungan yang berada di dalam daun kedondong bekerja kurang maksimal. Hal tersebut menyebabkan mikroorganisme yang berada pada piring makan tidak terbunuh secara optimal.

Michael J Peleczar, Jr., dan E.C.S CHAN (2008, h.487) menyebutkan, desinfektan yang ideal yaitu pada konsentrasi rendah, zat tersebut harus dapat mematikan berbagai macam mikroba.

e. Hasil Analisis Perbedaan Konsentrasi Ekstrak Daun Kedondong (Spondias dulcis) Dalam Menurunkan Angka Kuman Pada Piring

Analisis data multivariat menggunakan uji statistik digunakan untuk mengetahui perbedaan masing-masing konsentrasi yaitu $4 \%, 8 \%, 12 \%$ ekstrak daun kedondong terhadap angka kuman pada piring. Uji statistik yang digunakan adalah ANOVA yaitu untuk mengetahui ada perbedaan yang signifikan pada variasi konsentrasi ekstrak daun kedondong (Spondias dulcis) terhadap angka kuman pada piring makan di Kantin $\mathrm{X}$. Uji anova dapat dilakukan apabila syarat homogen data (Test of Homogenity of Variances) telah terpenuhi. Hasil Test of Homogenitiy of Variencesadalah seperti pada tabel 5.

Tabel 5: Test of Homogenity of Variences

\begin{tabular}{llll}
\hline $\begin{array}{l}\text { Levene } \\
\text { Statistic }\end{array}$ & df1 & df2 & Sig. \\
\hline 3,697 & 2 & 6 &, 090 \\
\hline
\end{tabular}

Berdasarkan tabel 5 hasil uji homogenitas menunjukkan bahwa nilai sig 0,090 yang artinya sig $>0,05$ berarti data varians homogen sehingga memenuhi syarat untuk dilakukan uji ANOVA.

Tabel 6: Hasil Uji ANOVA

\begin{tabular}{lccl} 
& Df & F & Sig. \\
\hline $\begin{array}{l}\text { Between } \\
\text { Groups }\end{array}$ & 2 & 1,233 & \multirow{2}{*}{, 356} \\
Within & 6 & & \\
Groups & & & \\
Total & 8 & & \\
\hline
\end{tabular}

Berdasarkan hasil uji ANOVA menunjukkan bahwa nilai sig 0,356>0,05 berarti tidak ada perbedaan penurunan angka kuman yang signifikan pada piring makan antara penggunaan konsentrasi $4 \%$, $8 \%$ maupun $12 \%$.

Uji analisis statistik perbedaan penurunan angka kuman pada piring, antara ekstrak daun kedondong dengan konsentrasi $4 \%, 8 \%, 12 \%$, didapatkan hasil bahwa tidak ada perbedaan penurunan angka kuman yang signifikan antar konsentrasi. Hal tersebut dapat disebabkan oleh banyak faktor, baik secara teknis penelitian maupun pengolahan data.

Wahyu Widhiarso (2011) menyebutkan penyebab hasil uji statistik tidak signifikan dikarenakan beberapa hal antara lain terjadinya kesalahan dalam mengentri data, model uji statistik yang tidak sesuai dengan data penelitian, ukuran sampel kecil, persyaratan analisis yang tidak dipatuhi, alat ukur yang kurang valid dan reliabel, dan penyebab lain.

\section{Simpulan dan Saran Simpulan}

Berdasarkan hasil penelitian yang telah dilakukan mengenai pengaruh pemakaian ekstrak daun kedondong (Spondias dulcis) sebagai desinfektan alami dalam menurunkan angka kuman pada piring makan di Kantin X Poltekkes Kemenkes Semarang, dapat diambil simpulan sebagai berikut:

a. Rerata angka kuman pada piring makan sebelum didesinfeksi menggunakan ekstrak daun kedondong (Spondias dulcis) adalah:

1) Konsentrasi $4 \% \quad: 240$ kolonicm $^{2}$

2) Kosentrasi $8 \% \quad: 215 \mathrm{koloni} / \mathrm{cm}^{2}$

3) Konsentrasi $12 \% \quad: 117 \mathrm{koloni} / \mathrm{cm}^{2}$

b. Rerata angka kuman pada piring makan sesudah didesinfeksi menggunakan ekstrak daun kedondong (Spondias dulcis) adalah:
1) Konsentrasi $4 \%$ : $33 \mathrm{koloni} / \mathrm{cm}^{2}$
2) Kosentrasi $8 \%$ : $73 \mathrm{koloni} / \mathrm{cm}^{2}$
3) Konsentrasi $12 \%$
: $43 \mathrm{koloni} / \mathrm{cm}^{2}$

c. Prosentase penurunan angka kuman pada piring makan sesudah didesinfeksi 
menggunakan ekstrak daun kedondong (Spondias dulcis)adalah:

1) Konsentrasi $4 \% \quad: 86,25 \%$

2) Kosentrasi $8 \% \quad: 66,04 \%$

3) Konsentrasi $12 \%: 63,24 \%$

d. Analisis pengaruh pemakaian ekstrak daun kedondong (Spondias dulcis)terhadap angka kuman pada piring menggunakan uji Paired $T$ Test. Hasil uji menunjukkan:

1) Konsentrasi $4 \%$ : nilai sig $0,174>$ 0,05

2) Konsentrasi $8 \%$ : nilai sig $0,126>$ 0,05

3) Konsentrasi $12 \%$ : nilai sig $0,194>$ 0,05

e. Analisis perbedaan masing-masing konsentrasi $(4 \%, 8 \%, 12 \%)$ ekstrak daun kedondong (Spondias dulcis) dalam menurunkan angka kuman menggunakan uji ANOVA, menunjukkan bahwa nilai sig $0,356>0,05$ berarti tidak ada perbedaan penurunan angka kuman yang signifikan pada piring makan antara penggunaan konsentrasi $4 \%, 8 \%$ maupun $12 \%$.

\section{Saran}

a. Sebaiknya pengelola kantin melakukan urutan teknik pencucian piring antara lain pembuangan sisa makanan, pembilasan awal, pencucian menggunakan detergen, pembilasan akhir, desinfeksi, dan pengeringan agar angka kuman pada piring dapat terminimalisir

b. Piring yang telah dicuci sebaiknya didesinfeksi dengan cara direndam dalam air panas dengan suhu $77^{\circ} \mathrm{C}$ selama 30 detik atau dengan larutan klor 50 ppm (2 sdm dalam 1 liter air) selama 1 menit

c. Piring yang telah dicuci sebaiknya disimpan di dalam rak tertutup yang terbuat dari bahan antikarat, rata dan tidak rusak serta terlindung dari serangga, tikus maupun hewan lain

\section{Daftar Pustaka}

Ahram, 2013, "Peralatan Makan Kotor Penyebab Keracunan Makanan Mahasiwa Al-Azhar", diakses pada 5 November 2017 pukul 21.27 WIB, dari http://www.voaislam.com/read/worldnews/2013/05/03/243 47/pejabat-peralatan-makan-kotorpenyebab-keracunan-makanan-mahasiswaalazhar/

Anwar dkk, Sanitasi Makanan dan Minuman Pada Institusi Pendidikan Tenaga Sanitasi, Jakarta: Pusat Pendidikan Tenaga Kesehatan Depkes RI.

Apriyati, 2015, Pengaruh Pemakaian Perasan Jeruk Nipis Sebagai Desinfektan Terhadap
Jumlah Angka Kuman Piring Makan di Kost Wijaya Kusuma Baturraden, Purwokerto: Politeknik Kesehatan Kemenkes Semarag Jurusan Kesehatan Lingkungan, KTI.

BPOM, 2006, "Keamanan Pangan Jajanan Anak Sekolah (PJAS)”, diakses pada tanggal 28 Oktober pukul 19.50 WIB, dari http://www.pom.go.id/mobile/index.php/vie w/berita/146/KEAMANAN-PANGAN-

JAJANAN-ANAK-SEKOLAH-$\underline{\text { PJAS-.html }}$

Dinafishy, 2016, "Flavonoid, Saponin, dan Alkaloid", diakses pada tanggal 9 Januari 2018 pukul 08.09 WIB, dari https://dinafishy.wordpress.com

Ditjen PPM dan PLP, 1997, Modul Penyehatan Makanan dan Minuman Untuk Petugas Puskesmas, Jakarta: Departemen Kesehatan RI.

1998, Pedoman Pembinaan dan Pengawasan Sanitasi Makanan, Jakarta: Departemen Kesehatan RI.

Hiasinta A. Purnawijayanti, 2001, Sanitasi Higiene dan Keselamatan Kerja Dalam Pengolahan Makanan, Yogyakarta: Kanisius

Hurri Inayati, 2007,"Potensi Antibakteri Ekstrak Daun Kedondong Bangkok (Spondias dulcis F)", diakses pada tanggal $27 \mathrm{Mei}$ 2017 pukul 09.24, dari http://repository.ipb.ac.id/

I Wayan Sudira, 2011, “Uji Daya Hambat Ekstrak Daun Kedondong (Lannea grandis Engl) Terhadap Pertumbuhan Bakteri Erwinia Carotovora" diakses pada tanggal 17 Oktober 2017 pukul 19.47, dari http://ojs.unud.ac.id

Jatmiko Susilo, “Uji Efektivitas Antibakteri Ekstrak Daun Kedondong Bangkok (Spondias dulcis L) Terhadap Bakteri Staphylococcus aureus Resisten Dan Escherichia coli Resisten" diakses pada tanggal 17 Oktober 2017 pukul 19.28, dari https://scholar.google.co.id

Kementerian Kesehatan RI, 2003, Keputusan Menteri Kesehatan RI Nomor 1098 Tahun 2003 tentang Persyaratan Higiene Sanitasi Rumah Makan dan Restoran, Jakarta: Menteri Kesehatan. 
2011, Keputusan Menteri Kesehatan RI Nomor 1096 Tahun 2011 tentang Higiene Sanitasi Jasa Boga, Jakarta: Menteri Kesehatan.

Lud Waluyo, 2007, Mikrobiologi Umum, Malang: UMM Press

Michael J Peleczar, 2008, Dasar Dasar Mikrobiologi. Jakarta: Universitas Indonesia (UI-Press)

Pemerintah RI, 2004, Peraturan Pemerintah RI Nomor 28 Tahun 2004 Tentang Keamanan Mutu Dan Gizi Pangan, Jakarta: Presiden RI

Plantamor, 2016, “Klasifikasi Kedondong”, diakses pada tanggal 25 November 2017 pukul 20.30

WIB, darihttp://www.plantamor.com/database/dat abase-tumbuhan/

Rara Marisdayana dkk, 2017, “Teknik Pencucian Alat Makan, Personal Hygiene Terhadap Kontaminasi Bakteri Pada Alat Makan", diakses pada tanggal 6 November 2017 pukul 18.40 WIB, dari http://ejournal.kopertis10.or.id/index.php/e ndurance/article/download/

Republik Indonesia, 2012, Undang-undang Nomor 18 Tahun 2012 Tentang Pangan, Jakarta: MENHUMHAM
Silvia Fitriani dkk, 2013, “Aktivitas Antifungi Ekstrak Daun Kedondong (Spondias pinnata) dalam Menghambat Pertumbuhan Aspergillus flavus", diakses pada tanggal 6 November 2017 pukul 20.05 WIB, dari http://jurnalmahasiswa.unesa.ac.id/article/4 523/33/article.pdf

Srikandi Fardiaz, 1996, Mikrobiologi Pangan, Jakarta: Gramedia Pustaka Utama

Tri Cahyono, 2014, Pedoman Penulisan Proposal Penelitian dan Karya Tulis Ilmiah / Skripsi ( Edisi Revisi Ketiga ), Purwokerto: Politeknik Kesehatan Kemenkes Semarang Jurusan Kesehatan Lingkungan.

Unoviana Kartika, 2014, "Keracunan Makanan Lebih Sering di Restoran”, diakses pada 5 November 2017 pukul 22.12, dari http://lifestyle.kompas.com/read/2014/04/1 2/1417261/keracunan.makanan.lebih.sering .di.restoran.

Wahyu Widhiarso, 2011, "Hasil Uji Statistik Tidak Signifikan, Mengapa?”, diakses pada 14 April 2018 pukul 22.53, dari http://widhiarso.staff.ugm.ac.id 